\title{
BIOECOLOGY OF DIORYCTRIA ABIETELLA DENIS AND SCHIFF. A PEST OF CONIFERS IN THE NORTH-WESTERN HIMALAYA
}

\author{
T.D. VERMA and R.K. GAUR \\ Department of Entomology \\ Dr. Y.S. Parmar University of Horticulture and.Forestry \\ Nauni-Solan-173 230, H.P., India
}

\begin{abstract}
Cones and seeds of conifers, such as Pinus roxburghii, P. wallichiana, P. gerardiana, Cedrus deodara, Abies pindrow and Picea smithiana are seriously damaged by Dioryctria abietella Denis and Schiff. (Lepidoptera : Pyralidae) in the North-Western Himalayan region of India. Bioecological studies carried out during 1991 - '92 revealed that the females laid whitish, elliptical eggs singly on the depressed surface of the young cones. The average egg size was $1.00 \pm 0.11 \times 0.60 \pm 0.08 \mathrm{~mm}$ and this stage lasted for 3 - 5 days. The larval stage passed through five instars. All the instars differed in appearance, size and duration and larvae became full-fed in an average of $24.8 \pm 1.9$ days. The full-fed larva spun a cocoon around itself, sealed it with white papery membrane and pupated inside the cone or any other outside protected place. The prepupal and pupal periods lasted for 7-8 and 10-14 days, respectively. The pupa was dark brown, 13.8 $\pm 0.07 \mathrm{~mm}$ in length. Total period from egg to adult varied from 46 to 59 days ( $52.7 \pm 4.8$ days $)$. Adults were dirty brown in appearance and were $13.59 \pm 0.115 \mathrm{~mm}$ long with an average wing expanse of $29.0 \pm 1.00$ $\mathrm{mm}$. They lived for 4 to 5 days. Under laboratory conditions, the pest completed two generations per year and full-fed larvae of 3rd generation overwintered during September - October. Two larval parasites belonging to order Hymenoptera and Diptera, and a fungal pathogen (Fusarium sp.) were found associated with this pest. The detailed biology, nature and extent of damage, along with its distribution have been discussed and methods of control suggested.
\end{abstract}

Key Words: Insect biology, Insect ecology, Dioryctria abietella, Coniferae, North-Western Himalaya, Forest pests

\section{INTRODUCTION}

Production of healthy seed is the backbone of afforestation programmes. Unfortunately this important aspect has so far been ignored in India. A high percentage of cone and seed crop is destroyed by insects every year resulting in great losses and adverse effect on the natural regeneration. At times the insect attack is so severe that the whole seed crop is destroyed.

Cone and seed insects of Indian conifers have not been studied in detail. Some of the important insects are the cone worms, Dioryctria abietella Denis and Shiff. (Lepidoptera : Pyralidae) and Cateremna cedrella Hampson (Lepidoptera : Pyralidae). Beeson (1941) and Browne (1968) gave brief accounts of the insects 
damaging cone and seed of conifers. Recently, Bhandari (1988) discussed the insect pests of cone and seeds of conifers and their control. In this paper an account of the life processes of $D$. abietella is given.

\section{MATERIALS AND METHODS}

Insect culture was raised from field collected overwintering larvae. The adults emerging from these larvae were held on 2 nd year green cones in wooden cages for mating and oviposition. Observations on the pattern, time and number of eggs laid and their incubation period were recorded. Freshly emerged larvae were carefully transferred with camel hair brush to small plastic jars, provided with fresh green cones. To avoid excess moisture inside the jars, a circular hole was cut in the centre of the lid and a piece of muslin cloth was fixed. The morphological characters and behaviour of the larval instars and the duration of each instar was recorded. The size of head capsule was also measured with the help of calibrated ocular micrometer which was taken as a criterion for differentiation of different instars. Full-fed larvae were transferred to glass jars $(15 \times 20 \mathrm{~cm})$ containing soil and cone scales and needles, for pupation. Parasites and pathogens associated with the insect were recovered from the culture in the laboratory and the percent parasitization was recorded. In addition, field surveys were also carried out at monthly intervals in coniferous forests to record the incidence, distribution and level of infestation of the pest. To determine the level of infestation fifteen cones were randomly observed from twenty trees selected at random in each locality.

\section{RESULTS AND DISCUSSIONS}

D. abietella is a borer of cones and seeds of Pinus roxburghii, P. wallichiana, P. gerardiana, Picea smithiana, Cedrus deodara and Abies pindrow in Himachal Pradesh. The biology of this pest on $P$. gerardiana, $P$. roxburghii, $P$. wallichiana, $P$. smithiana and $C$. deodara studied under laboratory condition revealed that the eggs were singly glued to the surface of cones generally in the depressions on the scales. Mathur et al. (1958) also reported that $D$. abietella eggs were whitish, elliptical and flattened, turning reddish brown after two days. The length and breadth of the eggs ranged from $0.86-1.10 \mathrm{~mm}$ (av. $1.00 \pm$ $0.11 \mathrm{~mm}$ ) and $0.54-0.73 \mathrm{~mm}$ (av. $0.60+0.08 \mathrm{~mm}$ ), respectively. The egg stage lasted for 3 - 5 days (av. $4.4 \pm 0.22$ days).

The larvae came out of the eggs by making a hole in the chorion in 30 - 40 minutes and entered the cone in about four hours. The larva is reddish brown with black head capsule. The width of the head capsule ranged from $0.31-0.34 \mathrm{~mm}$ 
(av. $0.33 \pm 0.00 \mathrm{~mm}$ ) (Table 1). The first instar larva measured 1.2-1.5 $\mathrm{mm}$ (av. $1.34 \pm 0.11 \mathrm{~mm}$ ) in length and the average duration was 3.6 days (Table 2). The second instar larva was light brown, 3.5-4.0 $\mathrm{mm}$ (av. $3.72+0.18 \mathrm{~mm}$ ) in length. The head capsule measured $0.51-0.56 \mathrm{~mm}$ (av. $0.53 \pm 0.01 \mathrm{~mm}$ ) in width. The second instar lasted for $4-5$ days (av. $4.5 \pm 0.16$ days).

The third and fourth instar larvae were dark brown with reddish brown head capsule. The width of head capsule of 3rd and 4th instar ranged from 0.80-0.95 mm (av. 0.87 $\pm 0.06 \mathrm{~mm}$ ), respectively. The body length varied from $9.50-12.00 \mathrm{~mm}$ (av. $10.59 \pm 0.85$ $\mathrm{mm}$ ) and $14.00-16.00 \mathrm{~mm}$ (av. $15.30 \pm 0.67 \mathrm{~mm}$ ) in two instars, respectively. The third instar lasted for 4- 5 days (av. 4.70 \pm 0.15 days) and fourth instar for 5 -6 days (av. $5.40 \pm 0.16$ days). The fifth instar larva was dirty brown along with dark brown head capsule. The width of head capsule ranged from $2.37-2.45 \mathrm{~mm}$ (av. $2.42 \pm 0.01 \mathrm{~mm}$ ) and measured $22.00-25.00 \mathrm{~mm}$ (av. $23.55 \pm 1.21 \mathrm{~mm}$ ) in length. This stage lasted for 6-7 days (av. $6.7 \pm 0.52$ days).

Table 1. The width of head capsule of larval instar of D. abietella (data based on 10 observations)

\begin{tabular}{llll}
\hline \multirow{2}{*}{ Instar } & \multicolumn{2}{l}{ Width of head capsule $(\mathrm{mm})$} & $\begin{array}{l}\text { Ratio of head } \\
\text { capsule width }\end{array}$ \\
\hline I & Range & Mean & - \\
I1 & $0.31-0.34$ & $0.33 \pm 0.00$ & 1.60 \\
III & $0.51-0.56$ & $0.53 \pm 0.01$ & 1.63 \\
IV & $0.80-0.95$ & $0.87 \pm 0,01$ & 1.65 \\
V & $1.39-1.47$ & $1.45 \pm 0.06$ & 1.67 \\
\hline
\end{tabular}

Table 2. Duration of different developmental stages of D. abietella (mean of 10 observations)

\begin{tabular}{llc}
\hline \multirow{2}{*}{ Stage } & \multicolumn{2}{c}{ Mean duration (days) } \\
\cline { 2 - 3 } & Range & Mean \pm S.E. \\
\hline Egg & $3-5$ & $4.4 \pm 0.22$ \\
Larva (Instar) & & \\
I & $3-4$ & $3.6 \pm 0.16$ \\
II & $4-5$ & $4.5 \pm 0.16$ \\
III & $4-5$ & $4.7 \pm 0.15$ \\
IV & $5-6$ & $5.4 \pm 0.16$ \\
V & $6-7$ & $6.7 \pm 0.15$ \\
Prepupa & $7-8$ & $7.6 \pm 0.16$ \\
Pupa & $10-14$ & $12.5 \pm 0.40$ \\
Adult & $4-5$ & $4.3 \pm 0.15$ \\
\hline
\end{tabular}



The larvae became full-fed in $22-27$ days (av. $24.8+1.93$ days). Mathur et al. (1958) reported that mature larvae were about $20 \mathrm{~mm}$ long, light reddish with blackish yellow head.

The full-fed larva constructed a cocoon before entering the pre-pupal stage. The cocoon was later sealed from all sides by means of white papery membrane. Pupation took place inside or on the surface of infested cones or on soil surface. The cocoon measured 16.00-20.00 mm (av. 18.80 $\pm 2.20 \mathrm{~mm}$ ) in length and 8.00-10.00 mm (av. $9.00 \pm 0.81 \mathrm{~mm}$ ) in width. The pre-pupal period lasted for $7-8$ days (av. $7.60 \pm 0.16$ days) and pupal period for 10-14 days (av. $12.50 \pm 0.40$ days). The pupa was dark brown, $13.50+14.10 \mathrm{~mm}$ (av. 13.80 $\pm 0.07 \mathrm{~mm}$ ) in length. However, Mathur et al. (1958) reported it to be light brown and about $10 \mathrm{~mm}$ long. Adults were dirty brown in appearance and were $13.00-14.00 \mathrm{~mm}$ (av. $13.59 \pm 0.11 \mathrm{~mm}$ ) long with wing expanse of 28.00-30.00 $\mathrm{mm}$ (av. $29.00 \pm 1.00 \mathrm{~mm}$ ). Beeson (1941) reported the wing expanse of the moth as 22 $34 \mathrm{~mm}$. Adults lived for 4 - 5 days (av. $4.30 \pm 0.15$ days). The egg laying started $1-2$ days of their emergence. A female laid 30-50 eggs (av. $42.40 \pm 6.78$ eggs) during her life time. Total period from egg to adult varied from 46-59 days (av. $52.7 \pm 4.80$ days). The insect completed two generations annually and full-fed larvae of third generation overwintered during the last week of September. The sex ratio in the laboratory reared population was 1 male to 1.5 female.

The natural enemies of the pest included two larval parasites (one each belonging to Hymenoptera and Diptera). Out of 160 larvae of the host, 39 hymenopteran and 15 dipteran parasites were collected which accounted to 24.37 and 9.38 percent infestation. A fungal pathogen Fusarium sp. was also isolated from the full-fed larvae.

The pest was found to be distributed throughout the inner and outer Himalayas of Himachal Pradesh. It infested C. deodara, P. wallichiana, P. smithiana, P. gerardiana, $P$. roxburghii in the region (Table 3$)$. The infestation was maximum $(89.06 \%)$ in Cedrus deodara cones around Shimla and by $70 \%$ at Chail in Solan

Table 3. Incidence of D. abietella on cone and seed of different conifers in Himachal Pradesh

\begin{tabular}{llccccc}
\hline \multirow{2}{*}{ District } & Locality/ & \multicolumn{5}{c}{ Percent infestation } \\
\cline { 3 - 7 } & Forest division & C. deodara & P. wallichiana & P. smithiana P. gerardiana & P. roxburghii \\
\hline \multirow{2}{*}{ Shimla } & Kasumpati & 89.06 & - & - & - & - \\
& Thanedhar & - & 52.00 & 11.00 & - & - \\
& Mashobra & 30.00 & 25.00 & 35.00 & - & - \\
\multirow{5}{*}{ Solan } & Chail & 70.00 & - & - & - & - \\
& Nauni & - & - & - & - & 14.72 \\
\multirow{2}{*}{ Kinnaur } & Sharbo & - & - & - & 30.43 & - \\
\hline
\end{tabular}




\section{BIOTROPIA No. 7, 1994}

district. In $P$. wallichiana, the maximum infestation (52\%) was recorded at Thanedhar. However, in $P$. smithiana the infestation level was only $11 \%$ in this locality. Whereas, at Mashobra in the Shimla district the infestation was $35 \%$ in $P$. smithiana, $30 \%$ in $C$. deodara and $25 \%$ in $P$. wallichiana. The infestation in $P$. gerardiana was $30.43 \%$ in the Kinnaur district of inner Himalayas. The incidence of this insect was comparatively low in $P$. roxburghii cones throughout the outer Himalayas, being maximum (14.72\%) at Nauni in the Solan district (Fig. 1)

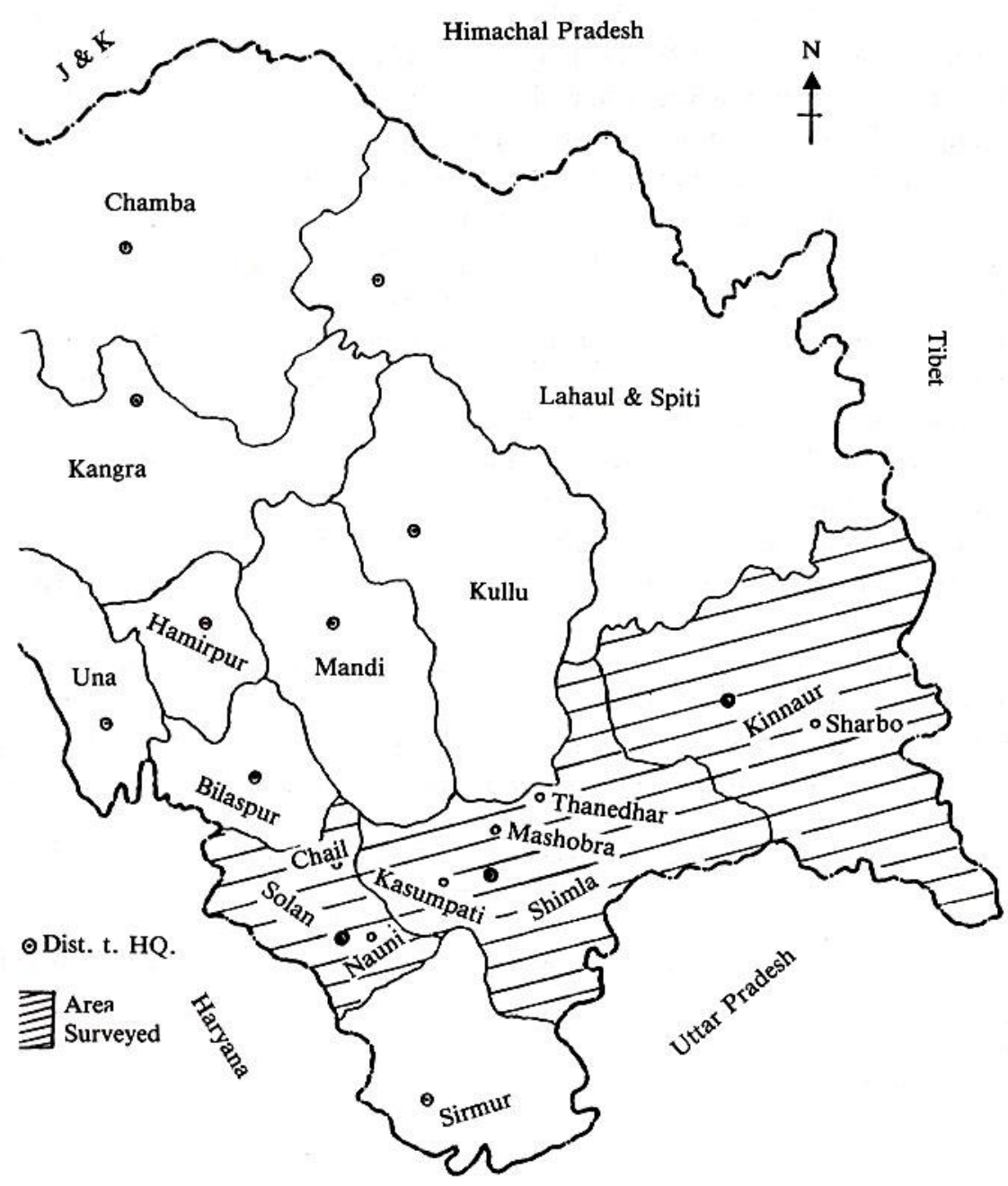

Figure 1. Incidence of Dioryctria abietella in coniferous forests 
It is practically difficult to control cone and seed insects in the natural forests. However, the pest population can be managed by collecting the infested cones and disposing them off together with the use of bio-control agents under the Northwestern Himalayan conditions.

\section{CONCLUSION}

A high percentage of cone and seed crop is destroyed by insects every year resulting in great losses and adversely affecting the natural regeneration of conifers. Numerous insects have been observed feeding casually on cone and seeds. But exceptionally $D$. abietella was found to be dominant. Under laboratory conditions, the insect had a total life span of 46 - 59 days and completed two generations in a year. During the course of investigation the larval parasites of Hymenoptera and Diptera suppressed the population to a great extent. Survey studies of this pest species revealed that $D$. abietella was widely distributed throughout the inner and outer Himalayan ranges of Himachal Pradesh especially on cones of Cedrus deodara and Pinus gerardiana. Continuous surveillance of this pest and its natural enemies is important in order to manage this pest.

\section{ACKNOWLEDGEMENTS}

The authors are thankful to the Indian Council of Forestry Research and Education, Dehradun for funding the present studies and Dr. O.P. Bhalla, Head, Department of Entomology for providing the necessary facilities.

\section{REFERENCES}

BEESON, C.F.C. 1941. Ecology and control of forest insects of India and neighbouring countries. Vasant

Press, Dehradun: 1007 p.

BHANDARI, R.S. 1988. Insect pests of cone and seed of conifers and their control. Tree protection:

342-347.

BROwNE, F.G. 1968. Pests and diseases of forest plantation trees. Clarendon Press Oxford: 1330 p.

MATHUR, R.N., B. SINOH, and K. LAL. 1958. Insects pests of flowers, seeds and fruits of forest trees. Indian For.

Bull. No. 223 (New Series) Entomology: 103 p. 